\title{
Myths and Realities: The Fallacy of Faculty Shortages in the Next Decade
}

\author{
MAX VON ZUR-MUEHLEN*
}

\begin{abstract}
This study confronts the popular conviction that Canadian universities are likely to suffer serious shortages of faculty in the 1990s. Despite an aging professoriate, faculty replacement demand will increase only gradually. Flexible retirement conditions and faculty renewal incentives have lessened the danger of a large simultaneous retirement, and increased demand due to growth is not likely. On the supply side, doctoral enrolment has increased substantially in recent years. Past cohort analysis and projections of enrolment trends indicate that the supply of doctoral recipients will be adequate at least until 1995. Furthermore, holding patterns for recent doctoral graduates and the coming of age of graduate programs in Canada suggest a flexible supply potential in response to any increased demand. This study concludes that in fact there will be a 2:1 faculty supply/demand surplus until at least 1990 and that such a situation will be maintained well into the 1990s.
\end{abstract}

\section{RÉSUMÉ}

Cette étude s'attaque à la conviction populaire qu'il y aura une pénurie de professeurs dans les universités canadiennes durant les années 1990. En dépit de l'âge avancé de la plupart du corps enseignant, la demande due au remplacement des professeurs ne s'accroîtra que graduellement. Des conditions de retraite flexibles ainsi que des programmes pour inciter le remplacement ont diminué le danger d'un retrait en bloc des professeurs dans les années 1990. Il est prévu que la demande d'enseignants se limitera à celle causée par le remplacement. Du côté de l'offre, les inscriptions au doctorat se sont accrues considérablement depuis quelques années. Basée sur une analyse des cohortes antérieures et sur les projections d'inscriptions, la présente étude prévoit une offre adéquate au moins jusqu'en 1995. En plus, des "postes d'attente » des diplômés récents de doctorat, ainsi que la maturation des programmes de 2 ième et de 3ième cycles impliquent

*Research Professor, University of Ottawa, Faculty of Administration. and Executive Director of the Canadian Higher Education Research Network (CHERN) 
que l'offre sera flexible face à toute éventuelle croissance de la demande. Cette étude arrive à la conclusion que l'offre d'enseignants sera deux fois plus élevée que la demande jusqu' en 1990, et que cette situation se maintiendra durant une bonne partie de la décennie suivante.

\section{INTRODUCTION}

A popular misconception in the recent academic literature is that there will be severe faculty shortages at Canadian universities in the 1990s. Such was the suggestion of the 1984 report of the Commission on Canadian Studies:

Canadian universities will again be confronted in the coming decade with an acute shortage of qualified teachers and with the consequent prospect of once more having to import teaching staff in large numbers from other countries. (p. 32)

These arguments also surface in the second Five-Year Plans (1985-1990) of the Social Sciences and Humanities Research Council (SSHRC) and the Natural Sciences and Engineering Research Council (NSERC). Each warned that the supply of doctoral degree holders might be inadequate to satisfy the university faculty demand in the next decade. The SSHRC noted:

If nothing is done over the next decade to remedy the situation, Canada will be forced once again to import large numbers of trained and experienced researchers from abroad in the 1990's. (p. 45)

NSERC stated:

In 1979, NSERC identified and quantified the scrious attrition rate of the existing professoriate which will commence in earnest about 1990 and accelerate rapidly through the 90's. This fact, coupled with a lack of faculty positions for young people during the 1980's translates into critical shortages of professors in the decade ahead. (p. 23)

This article attempts to demonstrate that, happily, the supply of Canadian university teachers in most disciplines is likely to be adequate for many years to come.

The case against probable faculty shortages can be divided into two parts: the demand for university teachers and the supply of doctoral graduates.

\section{The Anticipated Demand for University Teachers}

On the demand side, the situation in the 1990s will be quite different from that of the 1960s and early 1970s, which was characterized by a major influx of foreign professors. At that time, the Canadian university system was expanding at a phenomenal rate. Total full-time faculty nearly quintupled, rising from 6,500 in $1960-61$ to 31,600 in $1976-77$; on average, about 1,500 new positions were added annually from the sixties to the mid-seventies. Growth since then has been more gradual: a $12 \%$ increase to 35,500 in 1985-86. By contrast, in the 1990 s, with no foreseeable increase in university positions, replacement (i.e. due to retirement and mortality) will be the only significant demand factor. Moreover, 
demand may possibly be lessened by the demographically induced enrolment decline foreseen for the late 1980s and early 1990s and/or by downsizing due to financial constraints. Shifts in student preferences may also affect the demand for faculty in certain disciplines.

Many of the analyses that warn of impending faculty shortages have based their conclusions on the uneven age distribution of university teachers. In Ontario, for example, the Bovey Commission noted the skewed faculty age structure and its academic implications:

The abnormal faculty age distribution which has resulted from the dramatic increase in staffing in the 1960s and early 1970s has meant that with currently relatively few retirements, there are few openings for the present generation of young scholars and teachers. The presence of an appreciable number of talented new faculty would enhance instructional quality and adaptability and also assist in building up desired centers of strength in key developing fields of research and instructions. (p. 21)

The small number of recent tenure-stream appointments has indeed led to an under-representation of certain age groups and to the potential loss of a generation of scholars. The analyses by the Commission on Canadian Studies and the two granting councils are however, based on the somewhat unrealistic assumption that the age-structure of the present professoriate can be mechanically projected five to ten years hence without accounting for intervening variables such as outward and inward mobility, which rejuvenates the faculty age structure, and the future uncertainty of faculty retirement age.

In fact, most Canadian reports have suggested a sudden loss of university faculty when a large part of today's age pyramid reaches the mandatory retirement age of 65 . But current evidence indicates a more gradual retirement pattern. The Canadian Charter of Rights and Freedoms is likely to eliminate compulsory retirement at age 65 , as four provinces and the federal government have already done. At the same time, early retirement, work-sharing, faculty renewal and other incentive schemes have made the labour market for university teachers more flexible and dynamic. The magnitude of pension benefit schemes will also have an effect on the faculty's willingness to retire, as will inflation and the tax structure. The transition between employment and retirement in the 1990s will, therefore, differ greatly from the static assumptions made about it. The above-mentioned factors make any retirement projections exceedingly difficult and complicate the prediction of demand for university teachers.

In recent years, over 2,000 new university appointments have been made each year, representing an annual turnover of about 7 per cent. Half of these new appointments were inter-university transfers, both within Canada and from abroad; others were temporary or term replacements and the remainder were in the tenure stream. The majority (about $80 \%$ ) of the appointees were at the junior ranks. As a result, university faculty are not aging uniformly; the age structure is constantly being revitalized.

Another characteristic of the new entrants is that only two-thirds of them held a doctorate at the time of their appointment. While most of them may eventually 
TABLE I

DOCTORAL DEGREES BY DISCIPLINE AND BY FIELD OF STNOY, 1970 TO 1984

\begin{tabular}{|c|c|c|c|c|c|c|c|c|c|c|c|c|c|c|c|}
\hline $\begin{array}{l}\text { Discipline and } \\
\text { Fleld of Study }\end{array}$ & 1970 & 1971 & 1972 & 1973 & 1974 & 1975 & 1976 & 1977 & 1978 & 1979 & 1980 & 1981 & 1982 & 1983 & 1984 \\
\hline EDUCATION & 78 & 77 & 109 & 122 & 128 & 172 & 157 & 173 & 157 & 193 & 205 & 203 & 213 & 189 & 206 \\
\hline FINE AND APPLIED ARTS & 3 & 6 & 6 & 5 & 4 & 7 & 5 & 11 & 7 & 11 & 9 & 7 & 12 & 12 & 13 \\
\hline Classles & 3 & 2 & 16 & 7 & 7 & 7 & 10 & 3 & 7 & 11 & 10 & 10 & 5 & 3 & 1 \\
\hline Engilish & 50 & 51 & 48 & 64 & 66 & 79 & 79 & 67 & 74 & 82 & 63 & 87 & 54 & 64 & 68 \\
\hline French & 15 & 14 & 20 & 21 & 25 & 27 & 19 & 34 & 18 & 27 & 16 & 34 & 18 & 14 & 25 \\
\hline Other Modern Languages & 22 & 25 & 17 & 23 & 42 & 32 & 33 & 35 & 37 & 29 & 32 & 32 & 33 & 33 & 41 \\
\hline History & 29 & 37 & 49 & 35 & 47 & 61 & 55 & 52 & 48 & 54 & 39 & 39 & 42 & 40 & 42 \\
\hline Lingulstics & 4 & 5 & 4 & 8 & 6 & 11 & 12 & 7 & 12 & 11 & 10 & 16 & 14 & 13 & 2 \\
\hline Phillosophy & 15 & 32 & 31 & 44 & 50 & 44 & 33 & 35 & 48 & 56 & 41 & 40 & 41 & 58 & 41 \\
\hline Religlous Studles & 23 & 14 & 22 & 35 & 25 & 25 & 18 & 29 & 26 & 17 & 26 & 24 & 21 & 20 & 21 \\
\hline SUB-TOTAL HUMANITIES & 161 & 180 & 207 & 237 & 268 & 286 & 259 & 262 & 270 & 287 & 237 & 282 & 228 & 245 & 241 \\
\hline Archaeology & 1 & 1 & 1 & 4 & 6 & 1 & 2 & 1 & 3 & - & 2 & 5 & 8 & 1 & 3 \\
\hline Anthropology & 5 & 6 & 4 & 10 & 15 & 9 & 22 & 15 & 24 & 23 & 19 & 19 & 17 & 21 & 25 \\
\hline Areo Studles & 9 & 15 & 15 & 12 & 27 & 12 & 21 & 13 & 10 & 19 & 6 & 17 & 17 & 15 & 3 \\
\hline Management \& Admin. Studíes & $=$ & 4 & 7 & $i 1$ & 10 & 19 & 12 & 10 & 19 & 18 & 16 & 23 & 19 & 23 & 22 \\
\hline Environmental studies & 1 & 2 & 3 & 4 & 3 & 2 & 3 & 4 & 4 & 3 & 6 & 5 & 9 & 3 & 7 \\
\hline EconomIcs & 14 & 25 & 29 & 39 & 39 & 52 & 77 & 54 & 60 & 60 & 62 & 61 & 57 & 51 & 57 \\
\hline Geography & 14 & 18 & 22 & 25 & 31 & 39 & 28 & 30 & 31 & 28 & 24 & 29 & 26 & 26 & 30 \\
\hline Law & 3 & 15 & 10 & 4 & 4 & 7 & 9 & 5 & 4 & 6 & 3 & 8 & 3 & 18 & 7 \\
\hline Political Sclence & 7 & 9 & 8 & 18 & 19 & 20 & 19 & 25 & 26 & 30 & 19 & 27 & $2 \vec{i}$ & 22 & 34 \\
\hline Psychology & 86 & 119 & 109 & 121 & 133 & 148 & 153 & 142 & 169 & 154 & 184 & 185 & 152 & 155 & 169 \\
\hline Soclal work & 2 & i & 1 & 6 & 1 & 7 & 5 & 8 & 4 & 3 & 3 & 6 & 4 & 6 & 4 \\
\hline Soclology & 11 & 12 & 15 & 23 & 31 & 41 & 46 & 43 & 57 & 51 & 58 & 41 & 45 & 44 & 48 \\
\hline SUB-TOTAL SOCIAL SCIENCES & 153 & 227 & 224 & 277 & $3: 9$ & 357 & 397 & 350 & 411 & 395 & 402 & 426 & 378 & 385 & 409 \\
\hline TOTAL HUMAN SCIENCES & 395 & 490 & 546 & 641 & 719 & 822 & 818 & 796 & 845 & 886 & 853 & 918 & 831 & 831 & 869 \\
\hline
\end{tabular}


TABLE I (Cont'd)

DOCTORAL, DEGREES BY DISCIPLINE AN BY FIELD OF STUOY, 1970 TO 1984

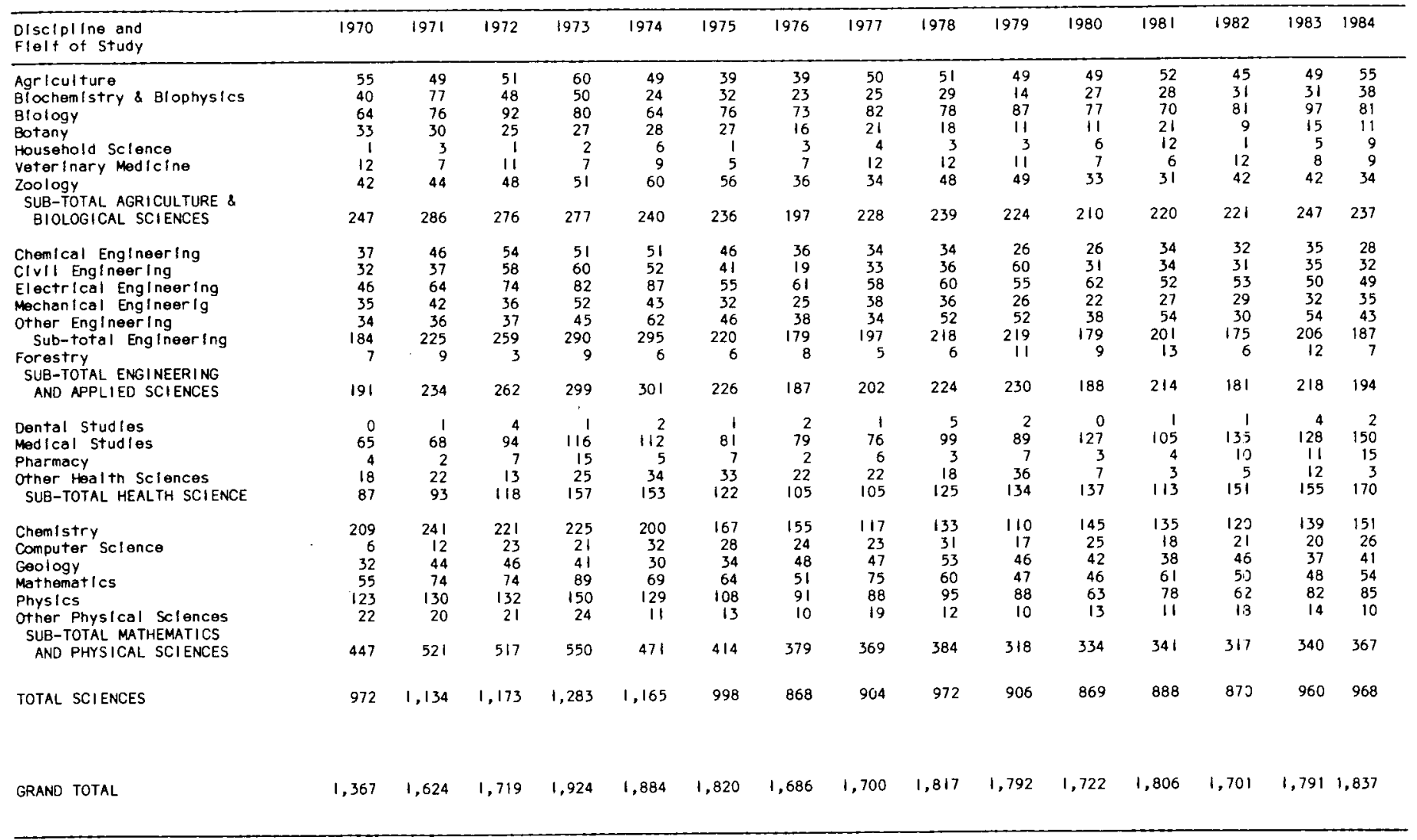


complete their doctoral degrees, this feature implies a certain flexibility in the labour market for university faculty.

All these factors contribute to a situation where the size of the replacement demand for university teachers is of neither the scale nor time frame suggested. Such uncertain demand considerations, however, must be related to future supply.

\section{The Projected Supply of University Teachers}

Most significant among faculty supply considerations are recent changes in full-time doctoral enrolment and in the subsequent anticipated supply of doctoral graduates from Canadian universities. During the last 10 years (1975 to 1984), an average of 1,750 doctorates were earned annually, 10 to 20 per cent of them by international (foreign) students (Table 1). At the same time, a sizable group of Canadian citizens and permanent residents is obtaining doctoral qualifications in other countries and then returning to Canada. (The National Research Council in the United States reported 327 doctoral recipients with Canadian citizenship or permanent resident status for 1983-84). The result has been that each year, a total of over 1,500 new doctoral degree holders (excluding international students, but including doctoral degree recipients returning from abroad) were potentially available to the labour market. Assuming that half of them would have liked to enter university teaching, as the pattern of the early 1980s suggests, 750 will be available each year between 1986 and 1990 (Table 2).

Recent studies have suggested that doctoral enrolment may be a function of employment opportunities for bachelor's degree-holders. This, however, seems to contradict the stable relationship between total university and doctoral enrolment which has been evident over the last decade. Another relationship which seems unlikely, for a variety of reasons, is the one between faculty supply/demand considerations and price elasticities. Moreover, salary structures, on a discipline basis, are not so much influenced by supply/demand factors as they are subject to the collective agreements in many universities which make salary differentiations difficult.

The simulation exercise in Table 2 is derived from 1985-86 data on full- and part-time doctoral enrolment of Canadian citizens and permanent residents. Based on past cohort analysis, the withdrawal rate and length of study were calculated, taking into account variations for each discipline by predicting the average annual number of doctoral degrees to be awarded during the five-year period between 1986 and 1990.

Although this simulation extends only to 1990 , indications from 1986-87 data are that the annual number of doctoral degrees awarded in Canada will actually increase. This is supported by the fact that full-time doctoral enrolment of Canadian citizens and permanent residents increased 27\% from 7,400 in 1981-82 to 9,400 in 1985-86 (Table 3) and by Statistics Canada's estimates, in Advance Statistics on Education 1986-87, that there will be 2,070 doctoral graduates in 1986 - substantially above the annual average for the last decade. In the early 
nineties, the supply of doctoral degree-holders is likely to be at least as high as that of the period from 1986 to 1990.

This prediction is supported by a second projection exercise, which extends the time horizon to a ten-year period from the mid-eighties to the mid-nineties. The relationship between total and doctoral full-time university enrolment is a stable one, as is the relationship between Master's and Doctoral degrees. During the last decade, doctoral students have consistently represented just over 2 per cent of total full-time university enrolment. Since total full-time enrolment is at an all-time high (estimated at 440,000 in 1986-87, excluding international students), continued growth of doctoral enrolment, and consequently the supply of doctoral graduates, can be predicted over the next decade. It takes about ten years from first-year enrolment to doctoral completion (including post-doctoral studies), so the potential supply of new university teachers can be projected with reasonable certainty to 1995 .

Another feature of present graduate enrolment is that the age distribution of doctoral students has shifted toward the older ages. This reflects the fact that more students are temporarily postponing graduate studies in order to gain experience or earn money; as a result, the time horizon for entry into the labour market as potential faculty is extended two or three years for students presently at the undergraduate level.

There are other aspects of the supply side that need to be considered. Since tenured positions have been limited in recent years, many doctoral graduates have entered "holding patterns". These include term and sessional appointments, and programs such as NSERC's University Research Fellowships and the SSHRC's new Canada Research Fellowships. These two programs also strengthen the research capacity of Canadian universities and in this sense serve a dual function. Provincial faculty renewal funding programs, such as those in Ontario and British Columbia, are another resource which have become popular as a means of rejuvenating faculty.

Another holding pattern is the increased number of female doctoral graduates, many of whom have not secured university employment. During the 1970s and early $1980 \mathrm{~s}$, the proportion of women among doctoral degree recipients increased from fewer than 1 in 10 to 1 in 4 , but proportionately fewer of them have been employed in universities. Only 16 per cent of full-time university teachers are women, and they tend to be concentrated in disciplines such as Education, Modern Languages and Literature, Nursing, and other Health Sciences.

Moreover, out of necessity, many recent doctoral graduates have entered other employment sectors, but still consider a university career their first choice and might, in the future, accept a university position.

These circumstances have created a reserve army of potential academics who could be activated when the need arises and when financial resources are available. Some of them may no longer be suited for a career shift to university employment, but on the other hand many of them have gained valuable experience in the private and public sectors. 

Projected supply of doctoral degrees tor Canadian citlizens and pernanent residonts for full- and part-time study,
by disclpline, 1986 to 1990

\begin{tabular}{|c|c|c|c|c|c|c|c|c|c|c|}
\hline $\begin{array}{l}\text { Discipline and } \\
\text { Field of Study }\end{array}$ & $\begin{array}{l}\text { Full-and } \\
\text { part-time } \\
\text { doctoral } \\
\text { enrolment }\end{array}$ & $\begin{array}{c}\text { wlth- } \\
\text { drawal } \\
\text { rate } \\
\text { in } \\
\text { percent }\end{array}$ & Balance & $\begin{array}{l}\text { Length } \\
\text { of } \\
\text { study }\end{array}$ & $\begin{array}{c}\text { Oegrees } \\
\text { granted } \\
\text { each year } \\
1986 \\
\text { to } \\
1990\end{array}$ & $\begin{array}{l}\text { Full-time } \\
\text { doctoral } \\
\text { enrolment }\end{array}$ & $\begin{array}{l}\text { with- } \\
\text { drawal } \\
\text { rate } \\
\text { In } \\
\text { percent }\end{array}$ & Balance & $\begin{array}{l}\text { Length } \\
\text { of } \\
\text { study }\end{array}$ & $\begin{array}{c}\text { Degroes } \\
\text { gronted } \\
\text { each your } \\
1985 \\
\text { to } \\
1990\end{array}$ \\
\hline EDUCATION & 1.779 & 50 & 890 & 5 & 178 & 1,020 & 50 & 510 & 5 & 102 \\
\hline $\begin{array}{l}\text { Music } \\
\text { FIne and pertorming arts } \\
\text { SUB-TOTAL FINE ANO PERFORMING ARTS }\end{array}$ & $\begin{array}{r}78 \\
45 \\
123\end{array}$ & $\begin{array}{l}50 \\
50 \\
50\end{array}$ & $\begin{array}{l}39 \\
23 \\
62\end{array}$ & $\begin{array}{l}5 \\
5 \\
5\end{array}$ & $\begin{array}{r}8 \\
5 \\
13\end{array}$ & $\begin{array}{l}56 \\
39 \\
95\end{array}$ & $\begin{array}{l}50 \\
50 \\
50\end{array}$ & $\begin{array}{l}28 \\
20 \\
48\end{array}$ & $\begin{array}{l}5 \\
5 \\
5\end{array}$ & $\begin{array}{r}6 \\
4 \\
10\end{array}$ \\
\hline $\begin{array}{l}\text { Classics } \\
\text { English } \\
\text { French } \\
\text { other languages } \\
\text { HIstory } \\
\text { Lingulstics } \\
\text { Pnllosophy } \\
\text { Religlous studies } \\
\text { SUB-TOTAL HUMANITIES }\end{array}$ & $\begin{array}{r}45 \\
481 \\
257 \\
295 \\
466 \\
148 \\
353 \\
280 \\
2,370\end{array}$ & $\begin{array}{l}50 \\
50 \\
50 \\
50 \\
50 \\
50 \\
50 \\
50 \\
50\end{array}$ & $\begin{array}{r}23 \\
241 \\
129 \\
148 \\
233 \\
74 \\
177 \\
140 \\
1.185\end{array}$ & $\begin{array}{c}5 \\
5 \\
5 \\
5 \\
6 \\
5 \\
4 \\
6 \\
6 \\
4+06\end{array}$ & $\begin{array}{r}5 \\
48 \\
26 \\
30 \\
39 \\
15 \\
44 \\
23 \\
230\end{array}$ & $\begin{array}{r}37 \\
406 \\
181 \\
242 \\
351 \\
102 \\
227 \\
199 \\
1,785\end{array}$ & $\begin{array}{l}50 \\
50 \\
50 \\
50 \\
50 \\
50 \\
50 \\
50 \\
50\end{array}$ & $\begin{array}{r}19 \\
203 \\
91 \\
121 \\
176 \\
51 \\
114 \\
100 \\
893\end{array}$ & $\begin{array}{c}5 \\
5 \\
5 \\
5 \\
5 \\
6 \\
5 \\
5 \\
4 \\
6 \\
4 \text { to } 6\end{array}$ & $\begin{array}{r}4 \\
41 \\
18 \\
24 \\
29 \\
10 \\
29 \\
17 \\
172\end{array}$ \\
\hline $\begin{array}{l}\text { Anthropology and archaeology } \\
\text { Area studies } \\
\text { Management and administrative studies } \\
\text { Economics } \\
\text { Geography } \\
\text { Law } \\
\text { Environmental studies } \\
\text { Poltical science } \\
\text { Psychology } \\
\text { Social work } \\
\text { SOClOlogy } \\
\text { SUB-TOTAL SOCIAL SCIENCES }\end{array}$ & $\begin{array}{r}234 \\
64 \\
259 \\
278 \\
166 \\
52 \\
35 \\
325 \\
1,283 \\
51 \\
436 \\
3,184\end{array}$ & $\begin{array}{l}50 \\
50 \\
50 \\
50 \\
50 \\
50 \\
50 \\
50 \\
50 \\
50 \\
50 \\
50\end{array}$ & $\begin{array}{r}117 \\
32 \\
130 \\
139 \\
83 \\
26 \\
18 \\
163 \\
642 \\
26 \\
218 \\
1,592\end{array}$ & $\begin{array}{c}5 \\
5 \\
5 \\
5 \\
5 \\
5 \\
5 \\
7 \\
4.5 \\
5 \\
5 \\
4.5 \\
40\end{array}$ & $\begin{array}{r}23 \\
6 \\
26 \\
28 \\
17 \\
5 \\
4 \\
23 \\
143 \\
5 \\
44 \\
324\end{array}$ & $\begin{array}{r}192 \\
40 \\
202 \\
207 \\
125 \\
39 \\
25 \\
237 \\
1,002 \\
30 \\
294 \\
2,394\end{array}$ & $\begin{array}{l}50 \\
50 \\
50 \\
50 \\
50 \\
50 \\
50 \\
50 \\
50 \\
50 \\
50 \\
50\end{array}$ & $\begin{array}{r}96 \\
20 \\
101 \\
104 \\
63 \\
20 \\
13 \\
119 \\
501 \\
15 \\
147 \\
1,197\end{array}$ & $\begin{array}{c}5 \\
5 \\
5 \\
5 \\
5 \\
5 \\
5 \\
7 \\
4.5 \\
5 \\
5 \\
4.5 \text { to } 7\end{array}$ & $\begin{array}{r}19 \\
4 \\
20 \\
21 \\
13 \\
4 \\
3 \\
17 \\
111 \\
3 \\
29 \\
244\end{array}$ \\
\hline TOTAL HUMAN SCIENCES & 7,456 & 50 & 3,728 & 4 to 7 & 745 & 5,294 & 50 & 2,647 & 4 to 7 & 528 \\
\hline
\end{tabular}

Source: Statistics Canada and estimates by the author. 
TABLE 2 (Cont'd)

Projected supply of doctoral degrees for Canadian cltizens and permanent residents from full-and part-time study, by disclpilne, 1986 to 1990

\begin{tabular}{|c|c|c|c|c|c|c|c|c|c|c|}
\hline $\begin{array}{l}\text { Discipline and } \\
\text { Field of Study }\end{array}$ & $\begin{array}{l}\text { Fuli- and } \\
\text { part-time } \\
\text { doctora! } \\
\text { enrolment }\end{array}$ & $\begin{array}{l}\text { With- } \\
\text { orawal } \\
\text { rate } \\
\text { in } \\
\text { percent }\end{array}$ & Balance & $\begin{array}{l}\text { Length } \\
\text { of } \\
\text { study }\end{array}$ & $\begin{array}{c}\text { Degrees } \\
\text { granted } \\
\text { each year } \\
1986 \\
\text { to } \\
1990\end{array}$ & $\begin{array}{l}\text { Full-time } \\
\text { ooctoral } \\
\text { encolment }\end{array}$ & $\begin{array}{l}\text { With- } \\
\text { drawal } \\
\text { rate } \\
\text { in } \\
\text { percent }\end{array}$ & Balance & $\begin{array}{l}\text { Length } \\
\text { of } \\
\text { study }\end{array}$ & $\begin{array}{c}\text { Degrees } \\
\text { granted } \\
\text { each year } \\
1986 \\
\text { to } \\
1990\end{array}$ \\
\hline Agriculture & 302 & 40 & 181 & 4 & 45 & 252 & 40 & 151 & 4 & 38 \\
\hline Blochemistry and blophysics & 136 & 40 & 82 & 4 & 21 & 128 & 40 & 77 & 4 & 19 \\
\hline Blology & 445 & 40 & 267 & 4 & 67 & 398 & 40 & 239 & 4 & 60 \\
\hline Botany & 63 & 40 & 38 & 4 & 10 & 60 & 40 & 36 & 4 & 9 \\
\hline Household sclence & 55 & 40 & 33 & 4 & 8 & $\begin{array}{l}00 \\
46\end{array}$ & 40 & 28 & 4 & 7 \\
\hline Veterinary medlcine & 53 & 40 & 32 & 4 & 8 & 46 & 40 & 28 & 4 & 7 \\
\hline Zoology & 172 & 40 & 103 & 4 & 26 & 151 & 40 & 91 & 4 & 23 \\
\hline $\begin{array}{l}\text { SUB-TOTAL AGRICULTURE \& } \\
\text { AND BIOLOGICAL SCIENCES }\end{array}$ & 1,226 & 40 & 736 & 4 & 184 & 1,081 & 40 & 649 & 4 & 162 \\
\hline Chemlcal enginearling & 116 & 45 & 64 & 4 & 16 & 103 & 45 & 57 & 4 & 14 \\
\hline Civll engineerling & 162 & 45 & 89 & 5 & 18 & 128 & 45 & 70 & 5 & 14 \\
\hline Electrical englneerling & 253 & 45 & 139 & 4 & 35 & 202 & 45 & 111 & 4 & 28 \\
\hline Mechanical engineering & 135 & 45 & 72 & 4 & 18 & 98 & 45 & 54 & 4 & 14 \\
\hline Other engl neering & 239 & 45 & 131 & 4 & 33 & 188 & 45 & 103 & 4 & 26 \\
\hline forestry & 69 & 45 & 38 & 5 & 8 & 57 & 45 & 31 & 5 & 6 \\
\hline SUB-TOTAL ENGINEERING \& APPLIED SCIENCES & 970 & 45 & 533 & $4-5$ & 128 & 776 & 45 & 427 & $4-5$ & 102 \\
\hline Dental studles & 10 & 35 & 6 & 3 & 2 & 9 & 35 & 6 & 3 & 2 \\
\hline Medical and other health studies & 814 & 40 & 488 & 4 & 122 & 682 & 40 & 409 & 4 & 102 \\
\hline Pharmacy & 112 & 35 & 73 & 4 & 18 & 96 & 35 & 62 & 4 & 16 \\
\hline SUB-TOTAL HEALTH SCIENCES & 936 & $35-45$ & 567 & $3-4$ & 142 & 787 & $35-45$ & 477 & $3-4$ & 120 \\
\hline Chomistry & 528 & 45 & 290 & 4 & 73 & 491 & 45 & 270 & 4 & 63 \\
\hline Computer sclence & 169 & 40 & 101 & 4 & 25 & 132 & 40 & 79 & 4 & 20 \\
\hline Geology & 210 & 35 & 136 & 4 & 34 & 158 & 35 & 103 & 4 & 26 \\
\hline Mathematics & 228 & 45 & 125 & 4 & 31 & 184 & 45 & 101 & 4 & 25 \\
\hline $\begin{array}{l}\text { Physics } \\
\text { Phes }\end{array}$ & 354 & 35 & 230 & 4 & 58 & 317 & 35 & 206 & 4 & 52 \\
\hline $\begin{array}{l}\text { Other physical sclences } \\
\text { thes }\end{array}$ & 128 & 35 & 83 & 4 & 21 & 110 & 35 & 71 & 4 & 18 \\
\hline SUB-TOTAL MATHEMATICS \& PHYSICAL SCIENCES & 1,617 & $35-45$ & 965 & 4 & $24 i$ & 1,392 & $35-45$ & 830 & 4 & 208 \\
\hline TOTAL SCIENCES & 4,749 & $35-45$ & 2,801 & 3 to 5 & 695 & 4.036 & $35-45$ & 2,383 & 3 to 5 & 592 \\
\hline GRAND TOTAL - ALL DISCIPLINES & 12,401 & $35-50$ & 6,637 & 3 to 7 & 1,464 & 9,463 & $35-50$ & 5,103 & 3 to 7 & 1,136 \\
\hline Other not Identifed disclpilines & 196 & 45 & 108 & 4.5 & 24 & 133 & 45 & 73 & 4.5 & 16 \\
\hline
\end{tabular}

Source: Statistics Canada and estimates by the author. 
TABLE 3

Full-time university students by level of study, 1972-73 to $1985-86$

\begin{tabular}{|c|c|c|c|c|c|c|}
\hline $\begin{array}{c}\text { Academic } \\
\text { year }\end{array}$ & $\begin{array}{l}\text { Under- } \\
\text { graduate }\end{array}$ & Master's & Doctoral & $\begin{array}{l}\text { Other } \\
\text { graduate }\end{array}$ & $\begin{array}{l}\text { Sub-total } \\
\text { graduate }\end{array}$ & Total \\
\hline $1972-73$ & $\begin{array}{r}272,627 \\
(90.3)\end{array}$ & $\begin{array}{r}17,080 \\
(5.6)\end{array}$ & $\begin{array}{l}7,263 \\
(2.4)\end{array}$ & $\begin{array}{l}4,996 \\
(1.7)\end{array}$ & $\begin{array}{r}29,339 \\
(9.7)\end{array}$ & $\begin{array}{r}301,966 \\
(100.0)\end{array}$ \\
\hline $1973-74$ & $\begin{array}{r}280,915 \\
(90.3)\end{array}$ & $\begin{array}{r}17,897 \\
(5.8)\end{array}$ & $\begin{array}{c}6,979 \\
(2.2)\end{array}$ & $\begin{array}{l}5,341 \\
(1.7)\end{array}$ & $\begin{array}{r}30,217 \\
(9.7)\end{array}$ & $\begin{array}{r}311,132 \\
(100.0)\end{array}$ \\
\hline $1974-75$ & $\begin{array}{r}293,098 \\
(90.4)\end{array}$ & $\begin{array}{r}18,795 \\
(5.8)\end{array}$ & $\begin{array}{c}6.334 \\
(2.2)\end{array}$ & $\begin{array}{c}5,219 \\
(1.6)\end{array}$ & $\begin{array}{r}30,948 \\
(9.6)\end{array}$ & $\begin{array}{r}324,045 \\
(100.0)\end{array}$ \\
\hline $1975-76$ & $\begin{array}{l}311,171 \\
(90.4)\end{array}$ & $\begin{array}{r}20,516 \\
(5.9)\end{array}$ & $\begin{array}{r}6,907 \\
(2.0)\end{array}$ & $\begin{array}{c}5,812 \\
(1.7)\end{array}$ & $\begin{array}{r}33,235 \\
(9.6)\end{array}$ & $\begin{array}{r}344,406 \\
(100.0)\end{array}$ \\
\hline $1975-77$ & $\begin{array}{l}315,784 \\
(90.5)\end{array}$ & $\begin{array}{r}20,683 \\
(5.9)\end{array}$ & $\begin{array}{l}6,871 \\
(2.0)\end{array}$ & $\begin{array}{l}5,326 \\
(1.5)\end{array}$ & $\begin{array}{r}32,880 \\
(9.4)\end{array}$ & $\begin{array}{c}348,664 \\
(100.0)\end{array}$ \\
\hline $1977-78$ & $\begin{array}{r}313,544 \\
(90.4)\end{array}$ & $\begin{array}{r}20,783 \\
(6.0)\end{array}$ & $\begin{array}{c}6,833 \\
(2.0)\end{array}$ & $\begin{array}{l}5,588 \\
(1.6)\end{array}$ & $\begin{array}{r}33,204 \\
(9.6)\end{array}$ & $\begin{array}{c}346,748 \\
(100.0)\end{array}$ \\
\hline $1978-79$ & $\begin{array}{r}307,118 \\
(90.0)\end{array}$ & $\begin{array}{r}21,207 \\
(6.2)\end{array}$ & $\begin{array}{l}6.808 \\
(2.0)\end{array}$ & $\begin{array}{c}6,156 \\
(1.8)\end{array}$ & $\begin{array}{c}34.171 \\
(10.0)\end{array}$ & $\begin{array}{c}341,289 \\
(100.0)\end{array}$ \\
\hline $1979-80$ & $\begin{array}{c}310,722 \\
(89.9)\end{array}$ & $\begin{array}{r}21,446 \\
(5.2)\end{array}$ & $\begin{array}{c}7.032 \\
(2.1)\end{array}$ & $\begin{array}{c}6.327 \\
(1.8)\end{array}$ & $\begin{array}{c}34,805 \\
(10.1)\end{array}$ & $\begin{array}{c}345,527 \\
(100.0)\end{array}$ \\
\hline $1980-81$ & $\begin{array}{c}318,954 \\
(89.7)\end{array}$ & $\begin{array}{r}22,372 \\
(6.3)\end{array}$ & $\begin{array}{l}7,190 \\
(2.0)\end{array}$ & $\begin{array}{l}6.916 \\
(2.0)\end{array}$ & $\begin{array}{c}36,478 \\
(10.3)\end{array}$ & $\begin{array}{c}355.432 \\
(100.0)\end{array}$ \\
\hline $1981-82$ & $\begin{array}{r}332.592 \\
(89.7)\end{array}$ & $\begin{array}{r}23.653 \\
(6.4)\end{array}$ & $\begin{array}{l}7.378 \\
(2.0)\end{array}$ & $\begin{array}{l}7,132 \\
(1.9)\end{array}$ & $\begin{array}{c}38,163 \\
(10.3)\end{array}$ & $\begin{array}{c}370,755 \\
(100.0)\end{array}$ \\
\hline $1982-83$ & $\begin{array}{r}352,062 \\
(89.6)\end{array}$ & $\begin{array}{r}25.346 \\
(6.5)\end{array}$ & $\begin{array}{l}7.861 \\
(2.0)\end{array}$ & $\begin{array}{c}7.454 \\
(1.9)\end{array}$ & $\begin{array}{c}40,661 \\
(10.4)\end{array}$ & $\begin{array}{c}392,723 \\
(100.0)\end{array}$ \\
\hline $1983-84$ & $\begin{array}{r}373,092 \\
(89.5)\end{array}$ & $\begin{array}{r}27,574 \\
(6.6)\end{array}$ & $\begin{array}{c}8,571 \\
(2.1)\end{array}$ & $\begin{array}{l}7,565 \\
(1.8)\end{array}$ & $\begin{array}{c}43,710 \\
(10.5)\end{array}$ & $\begin{array}{c}416,802 \\
(100.0)\end{array}$ \\
\hline $1984-85$ & $\begin{array}{r}383,388 \\
(89.4)\end{array}$ & $\begin{array}{r}28,320 \\
(6.6)\end{array}$ & $\begin{array}{r}9,312 \\
(2.2)\end{array}$ & $\begin{array}{l}7,654 \\
(1.8)\end{array}$ & $\begin{array}{r}45,286 \\
(10.6)\end{array}$ & $\begin{array}{r}428,674 \\
(100.0)\end{array}$ \\
\hline $1985-86^{P}$ & $\begin{array}{r}392,051 \\
(89.6)\end{array}$ & $\begin{array}{r}28,451 \\
(6.5)\end{array}$ & $\begin{array}{l}9,368 \\
(2.1)\end{array}$ & $\begin{array}{l}7.702 \\
(1.8)\end{array}$ & $\begin{array}{r}45,521 \\
(10.4)\end{array}$ & $\begin{array}{r}437.572 \\
(100.0)\end{array}$ \\
\hline
\end{tabular}

Note: Excludes international (foreign) students.

Source: Statistics Canada. 
The university environment of the 1990s will differ substantially from that of the past and present in a variety of respects. In the last two decades, Canadian universities have greatly developed their graduate programs. These programs are achieving maturity in the 1980s, and will enable Canadian universities to respond to demands for highly qualified manpower much more readily and expeditiously than in the sixties and early seventies when the infrastructure did not exist. The anticipated adequacy of supply is fortuitous, because it is unlikely that other industrial countries, particularly the United States, will have a surplus of university teachers as their own universities experience a strong replacement demand. An international shortage of university teachers already exists in a number of key areas such as management and the technology-intensive fields, as well as in some applied disciplines of the humanities and social sciences.

\section{The Future Demand for and Supply of University Teachers}

In re-interpreting the demand and supply factors for university teachers for the next ten years, an overall picture very different from the one suggested by the two granting councils and the Commission on Canadian Studies is emerging. These reports, which reflected the perceptions of the early eighties, were based on assumptions that were cumulatively biased on both the supply and demand sides, thereby compounding the possibility of error and creating the scenario of a future imbalance. This led to dramatic assertions that Canada would face a severe shortage of university teachers in the 1990s.

Table 4 shows calculations of doctoral supply and demand relating to university teachers, 1986 to 1990, and considers retirement and mortality patterns for the same period. This table indicates, on a discipline basis, the anticipated surplus or deficit without considering the demand due to growth or to possible quality improvements. These calculations also do not take into account international students with doctoral qualifications, visiting scholars who stay on in Canada and eventually become permanent residents, nor future immigrants. Such variables contribute further to the supply data. Annual replacement demand (retirement and mortality), derived from the present age structure, would be 500 to 600 annually. Only two-thirds (i.e., 330 to 400 ) of the entry positions likely to be open will require doctoral qualifications. This figure can be compared with the predicted supply of 1,500 doctoral degrees (including returning Canadians) awarded each year. As suggested earlier, a minimum of half of them (750) would be available for university teaching.

Therefore, the supply-demand ratio is two to one. Thus, while current literature presumed a somewhat reversed ratio, and consequently a dangerous faculty shortage, the available evidence refutes the suggestion of an imminent faculty supply crisis in the 1990s. Even if some of the premises are modified, on both the supply and demand sides, this outcome would not be dramatically affected. Only under radically different assumptions, such as exceptionally strong growth in the Canadian economy, a substantial increase in research and development expenditures, or a massive injection of financial resources to reduce the student-faculty 
TABLE 4

ESTIMATED SUPPI,Y OF IXOCTORAL, DEGREES FOR UNIVERSITY TEACHING REIATED TO THE REPIACEMENT DEMAND, 1986 TO 1990

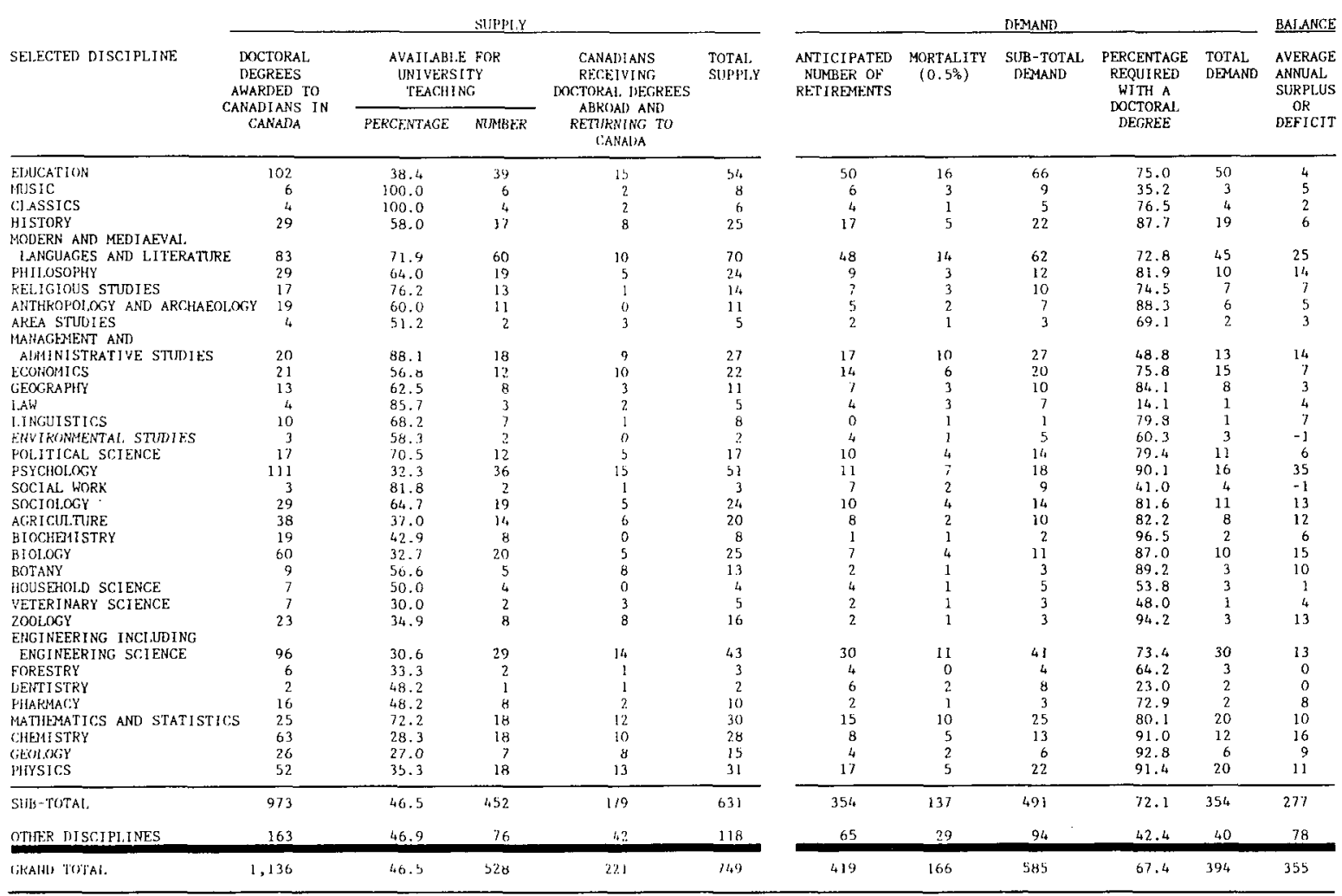

Source: Derived from Table 2 and estimates by the atthor. 
ratio, might there be a shortage of university faculty with doctoral qualifications. These possibilities seem very remote.

The overall analysis presented here, which covers well over 50 disciplines, has to be modified for specific disciplines in which enrolment might decline and replacement positions might not be filled, and for those which might grow such as management or computer science. If demand due to growth persists, the doctoral supply may be inadequate for these disciplines. Thus, for each of the over 50 disciplines, a different supply-demand profile emerges. Since substitution between disciplines is limited, demand and supply for each one must be addressed separately, but the overall picture is not changed. Invariably, most disciplines will have substantial surpluses of potential university teachers. The majority of doctoral degree holders will, however, have alternate employment opportunities.

It is always tempting to speculate on the future, even without an adequate information base, since one is unlikely to be held accountable. The popular assumption of impending severe faculty shortages appears to be a reflection of this syndrome and seems to have been accepted as a truism. However, this is not only unfair to potential doctoral students who might be considering university teaching as a career, but also poses the danger of a misallocation of scarce resources. The argument in favour of additional resources for doctoral training should not be based on projected shortages of highly qualified manpower in the next decade.

\section{CONCLUSION}

Recent predictions of another staffing crisis in Canadian universities in the 1990s appear to be myths. Of course, individual disciplines may experience shortages; some, such as business or electrical engineering, do today. It is exceedingly difficult to achieve a perfect balance in the employment market for university teachers, since student choices, financial support for students, budgetary constraints, and incentive programs influence both supply and demand. A long lead time is necessary to complete a doctoral degree, whereas the labour market demand changes rapidly. Also, university appointments often require very specific qualifications and work experience. It may still be necessary for Canada to rely on the international labour market for certain specialized talent. Nonetheless, the apparent adequate supply of doctoral degree holders for the next ten years resolves some uncertainties for the universities and the government, and is welcome news.

\section{REFERENCES}

The Commission on the Future Development of the Universities of Ontario (Bovey Commission), Ontario Universities: Options and Futures (Toronto: December 1984).

Natural Sciences and Engineering Research Council. Completing the Bridge to the 90's. A Second Five-Year Plan for the Programs of the Natural Sciences and Engineering Research Council (Ottawa: NSERC, June 1985).

Social Sciences and Humanities Research Council, Canada. Five-Year Plan for Financing Research in the Social Sciences and Humanities. 1985-1990 (Ottawa: SSHRC, 1985).

Symons, T. H. B. and Page, J. E. Some Questions of Balance: Human Resoures, Higher Education and Canadian Studies (Ottawa: Association of Universities and Colleges of Canada, 1984). 